This article has been published in a revised form in Modern Italy, https://doi.org/10.1080/13532944.2011.594999.

This version is free to view and download for private research and study only. Not for re-distribution, re-sale or use in derivative works. (c) Association for the study of Modern Italy.

\title{
The determinants and barriers to critical consumption: a study of Addiopizzo
}

\author{
Henry Partridge* \\ Department of Security and Crime Science, \\ University College London
}

\begin{abstract}
'Addiopizzo' (Goodbye protection money) is a grassroots antimafia movement based in Palermo that stresses the individual consumer's responsibility for maintaining the Sicilian Mafia's pizzo system. If you purchase products from a business that pays the pizzo you are indirectly supporting the Mafia. By encouraging Palermitans to buy from 'pizzo-free' businesses, Addiopizzo uses the purchasing power of the consumer to fight organised crime.
\end{abstract}

The community of 'pizzo-free' businesses is small but steadily growing whilst the number of critical consumers pledging to buy their products appears to have peaked. This article aims to investigate the reasons why consumers may be reluctant to support 'pizzo-free' businesses by asking those who have already made public their decision to do so. Whilst critical consumers cannot fully explain why the majority of Palermo's citizens continue to tolerate the pizzo system their attitudes towards them do highlight differences that may help to account for wider non-participation in Addiopizzo's campaign.

Keywords: Addiopizzo, antimafia, protection money, Sicily, social movements

Table 1: $\quad$ Sample profile

Table 2: $\quad$ Profile of sample and population by quarter of residence

Figure 1: Factors influencing decision to join Addiopizzo

Figure 2: Likely reasons for non-membership of Addiopizzo

Figure 3: Reasons for the persistence of the pizzo system

Figure 4: Importance of the actions of various organisations and groups at eliminating the pizzo system

Figure 5: Levels of Addiopizzo membership, May 2005-April 2011

Figure 6: The diffusion of pizzo-free businesses and Addiopizzo consumers in the and quarters of Palermo in March 2010 


\section{Introduction}

Andrea Camilleri, best-selling author of the Commissario Montalbano crime novels, made headlines in September 2007 when he suggested in an interview with the Corriere della Sera that the Italian army should be sent to Sicily to protect businesses who refuse to pay protection money to the mafia (Corriere della Sera, 17.09.07). His comments came after the employers' federation Confindustria announced that it would expel members who refused to denounce their extortionists to the police (La Stampa, 07.09.07). Confindustria's decision had been prompted by an increase in the ferocity of attacks against business owners most notably Andrea Vecchio, a Catanian construction contractor whose sites had been fire-bombed over four successive days, and Marco Venturi, President of Caltanissetta's Chamber of Commerce who had received death threats (Corriere della Sera, 02.09.07). Camilleri argued that the rise in attacks against Sicilian businesses was a result of the leadership vacuum created by the arrest of Bernardo Provenzano in April 2006. Enforcing the collection of protection money with threats and arson attacks is one method that rival mafia groups use to assert their territorial control. Whilst he welcomed Confindustria's decision to expel members who refused to report their extortionist to the police, Camilleri warned that it was likely to lead to increased mafia aggression against businesses. 'The Mafia cannot afford to let too many people say no. This would be its downfall. The reactions are predictable. The risks increase. Expect something' (Corriere della Sera, 17.09.07). Many including a number of local mayors agreed with Camilleri that the army should be deployed to protect businesses but others weren't convinced. Tano Grasso, founder of the first anti-racketeering group in Italy said in an interview with Reuters news agency: 'The army would be no help at all. What we need is an army of shopkeepers who denounce this in public' (Reuters, 22.10.07).

The community of businesses and consumers known as Addiopizzo is one such 'army of shopkeepers'. Based in Palermo, Addiopizzo is a grassroots movement of approximately 670 businesses and 10,000 consumers who refuse to pay 'pizzo', or protection money to the Sicilian Mafia. ${ }^{1}$ Together these businesses and consumers find safety in numbers. Businesses show their solidarity with other businesses by refusing to pay protection money and consumers reward them by pledging to buy 'pizzo-free' goods from their shops.

Addiopizzo represents what La Spina (2008a, 196) calls an 'indirect' antimafia strategy that complements the investigative and other 'repressive' powers available to the police and judiciary by 'reinforcing and spreading attitudes and behaviours which can pose serious obstacles to the day-to-day activities of mafia men'. Addiopizzo is a social movement that stresses the individual consumer's responsibility for maintaining the pizzo system. If you buy products from a business that pays the pizzo you are indirectly helping to finance the Mafia. By encouraging Palermitans to buy from pizzo-free businesses, Addiopizzo uses the purchasing power of the consumer to fight organised crime. ${ }^{2}$

The community of 'pizzo-free' businesses that belong to Addiopizzo is small but steadily growing whilst the number of critical consumers pledging to buy their products appears to have peaked. Businesses joining Addiopizzo grew by 173\% from 252 in April 2008 to 688 in April 2011 but the number of critical consumers increased by only $8.3 \%$ over the same period from 9,318 to 10,090 . Why are there so few new consumers prepared to support business that denounce the mafia with their purchases? The business owner who refuses to pay pizzo faces considerable personal and financial risk but purchasing their 'pizzo-free' products is a largely anonymous and therefore risk-free activity (Micheletti 2010, 10). By using a web hosted survey to solicit the views of Addiopizzo members this article hopes to gain a better understanding of the motives that lead consumers to support pizzo-free businesses with their purchases and the reasons why others may be reluctant to do so. 
Unfortunately, the survey data collected was inadequate to answer the research question in the way the author intended. The resulting low response rate $(3.4 \%)$ and demographically limited sample profile meant that only hypothetical reasons could be given for wider nonparticipation in Addiopizzo's campaign. However, the responses did provide an insight into some of the attitudes that Addiopizzo supporters hold towards other perhaps poorer and less educated Palermitan consumers. These attitudes reveal a conflict between the civicmindedness that inspired respondents to join Addiopizzo and a prevailing fatalism that appears to tolerate the pizzo system. This divide illustrates a key weakness in the Addiopizzo movement: its support rests on a minority of Palermitan society. In order to promote a 'cultural revolution' against the Mafia's pizzo system Addiopizzo needs to appeal to a broader social base of support.

This paper is structured to give the reader a general understanding of the mechanics of the pizzo system and what is involved in resisting it. It then proceeds with a presentation and discussion of the survey results and ends with a set of recommendations that are designed to help Addiopizzo appeal to a wider social base of support.

\section{Background}

\section{The pizzo system}

'Pizzo' is protection money that legal and illegal businesses pay to the Mafia. The word pizzo derives from the Sicilian pizzu, which refers to the beak of a bird (Dickie 2007, 55). To let mafiosi 'wet their beak' (fari vagnari 'u pizzu) is therefore to pay protection money to them. It is an appropriate metaphor because the Mafia extorts a nominal but regular amount of protection money from a variety of businesses in the same way that a bird sips from different watering holes: fountains, baths, puddles etc.

The collection of pizzo is not confined to Sicily but is also practiced by the three other main Italian Mafias on the mainland: the Camorra of Campania (Di Gennaro and La Spina 2010); the Calabrian 'Ndrangheta (Ciconte 2008); and the Sacra Corona Unita of Apulia. ${ }^{3}$ According to reliable recent estimates from the Fondazione Rocco Chinnici, the average annual amount paid by businesses in the provinces of Naples and Caserta to the Camorra clan was $€ 950$ million or $2 \%$ of the area's wealth (Lisciandra 2010, 161). In Sicily, the cost of protection was $€ 1$ billion or $1.4 \%$ of Sicily's gross regional product in 2006 (Asmundo \& Lisciandra 2008, 238).

There are two main reasons why the Mafias collect protection money: financial and territorial. The proceeds from protection are typically used to pay salaries, support the families of those in jail, and to cover legal costs (Mete 2008b). The payment of protection money, as magistrate Giovanni Falcone observed, is also 'tangible recognition of the criminal organization in the territory, and in this sense is a sort of fee for the organization that controls it' (quoted in Sciarrone 2009, 11).

It is estimated that $70 \%$ of Sicilian shops and $80 \%$ of businesses in Palermo pay protection money to the Sicilian Mafia, Cosa Nostra (SOS Impresa 2007,17; 9). The Fondazione Rocco Chinnici has given a more conservative figure of $58 \%$ for the whole of Sicily (Asmundo \& Lisciandra 2008, 238). The amount of protection money paid by businesses is progressive because those with larger revenues pay a higher percentage than those with smaller revenues. One recent study shows that protection money starts at a minimum monthly request of $€ 32$ for a tobacconist to a maximum of about $€ 27,200$ a month for a big supermarket (Asmundo \& Lisciandra 2008, 228). These estimates are confirmed by the notes of Mafia boss Salvatore Lo Piccolo published in La Repubblica in December 2007, which gave the names of 170 businesses and the protection money they owed (La Repubblica, 27.12.07). Payments range 
from around $€ 500$ for a pizzeria to $€ 30,000$ for bigger businesses. Bernardo Provenzano insisted that businesses 'pagare poco, ma pagare tutti' (pay little, but everyone pays) (La Spina 2008a, 122). The amount paid is not intended to cripple businesses but 'to be sufficiently tolerable (as it is not incredibly high) in relation to the firm's cash and budget flow' (Asmundo \& Lisciandra 2008, 227). As a result, protection money is considered a normal outgoing for most businesses.

The payment of protection can take many forms (Gambetta 1993, 179-182). Typically a monthly amount is paid but a share of a business' profits can also be made at Easter and Christmas time. There are also one off payments which in the case of public works contracts mean a fixed percentage. Payment can also be made in kind if a business is not doing too well financially (Asmundo \& Lisciandra 2008, 222, n1). Fish, jewellery, clothes etc. can be paid instead of money. Discounts and credit can also be offered. The enforced purchase of goods from protected mafia suppliers (Gambetta 1993, 181) is also a means of payment. Buying goods from such suppliers converts 'payment for protection into further protection for [the mafioso's] local clients'. The imposition of mafiosi as employees and even businesses copartners are other forms of payment and the most blatant form of the mafia's expropriation of businesses through the imposition of protection.

The payment of protection money in whatever form represents a direct cost to businesses but there are also other less obvious 'indirect' costs. Asmundo and Lisciandra (2008, 222) split the costs of extortion into three groups: anticipatory, as a response, and consequential. Anticipatory costs are incurred by businesses that do not pay protection money but could be intimidated into doing so with damage to their property or theft. Insurance and security would represent these kinds of anticipatory costs. There are also costs as a response to extortion. Most of these concern the legal costs of reporting and pursuing an extortionist through a court of law. Finally, there are less easily measurable consequential costs of extortion, namely fear and suffering.

However, the costs of paying protection money are not always negative. Asmundo and Lisciandra $(2008,222)$ identify some of the primary and secondary 'benefits' of paying protection. The primary benefits consist in the survival of the protected business. For example, unprotected businesses pay hefty anticipatory costs to insure against possible theft or criminal damage from would-be extortionists whilst protected businesses incur the much smaller financial costs of protection. The benefits to businesses consist in the additional services that protection provides. These services include protection against rival extortionists (Gambetta 1993, 174-7); the elimination of competition (Varese 2011, 6); access to mafiacontrolled markets and suppliers; intimidation of customers, workers and trade unionists (Gambetta 1993, 93-4; Varese 2011, 6); and the enforcement of cartel agreements (195-225). Clearly, as Gambetta observes, 'mafia protection cannot be dismissed as invariably bogus or extortionate [...] such services are often useful to and actively sought by customers' (187).

It is not always clear whether the business owner is paying protection money out of fear or benefit. As Mete (2008b) points out, some companies 'remain active and do business very profitably not in spite of the mafia, but thanks to the mafia.' The business owner paying protection money represents a clear example of 'ambiguous victimhood' (Schneider \& Schneider 2003, 219). Only those who pay the pizzo out of fear can be regarded as victims but it is hard to tell if a business owner who initially paid protection money out of fear can be classed in the same way if he is benefitting from mafia involvement. As the deputy prosecutor, Guido Lo Forte said at the Maxi-Trials: 'it is very difficult to establish, in each particular case, where the passive action imposed by the mafia ends and where active involvement in mafioso activities begins' (quoted in Gambetta 1993, 188).

La Spina $(2008 \mathrm{a}, 196)$ argues that those who 'cooperate with the mafia not on the basis of fear, but rather because such actions produce an illegitimate gain [...] should be discouraged 
and punished'. It is difficult to know whether such a punitive approach would lead to a rise in complaints against extortionists but Addiopizzo's strategy of giving businesses access to a market of critical consumers gives those who accept mafia protection out of fear and those who benefit from it a financial incentive to report it.

\section{Addiopizzo}

Addiopizzo is a grassroots movement of businesses and consumers who refuse to pay 'pizzo' to the Sicilian mafia. It began in 2004 when a group of young Palermitans discussed opening a bar in the city. Listing their likely outgoings: rent, utility bills, beer ... one of them observed: 'What if they ask us for the pizzo?' Resentful of the imposition of protection money some of the group clandestinely posted stickers around the city centre during the night of 2829 June. The stickers were edged with a black border like traditional Sicilian necrologie or death notices and read: 'Un intero popolo che paga il pizzo è un popolo senza dignità' ( $A$ whole people who pays the pizzo is a people without dignity). The message was clear: a city that pays protection money should be ashamed of itself.

The media-labelled 'Comitato degli adesivi' (Stickers Committee) initially remained anonymous but explained their motives in an interview with the newspaper Giornale di Sicilia and in an open letter published in the Palermitan edition of La Repubblica on 1 July. The group sought to break the taboo of talking about the pizzo:

[E]very business that makes a good turnover, if it is not a 'friend of the friends' must pay protection money. Everyone, without exception. Little maybe, but all pay money 'to be protected'. This is well-known by all Sicilians. And every day forgotten. Have we ever thought that while doing our daily shopping we give money also to the Mafia? Of course not, yet it is so. If the bakeries, the clothes shops, tobacconists, bars, butchers, office supply stores, fishmongers, libraries, ice-cream parlours, cinemas, florists, toy shops, funeral directors and so on and so forth, are forced to pay protection money, they do so with the money that we spend at all of these businesses. 4

The posting of stickers was a way of raising awareness amongst Palermo's citizens that each of them was responsible for maintaining the pizzo system albeit indirectly by shopping at businesses that pay protection money to the Sicilian mafia.

A few months later, the campaign 'contro il pizzo cambia i consumi' (change consumption against the pizzo) was launched. This campaign encouraged consumers to sign a commitment to shop in stores that openly denounced the pizzo. Within a few weeks some 3,500 signatures had been raised (Forno \& Gunnarson 2010, 112). Later in May 2006, a list was published containing over 100 businesses that were all prepared to publically denounce the pizzo. Since then Addiopizzo has actively sought to build alliances between critical consumers and businesses that refuse to pay protection money.

Influenced by the tactics of the political consumerist movement Addiopizzo has adopted a market-based strategy for fighting organised crime. 'To us, who have been part of the Social Justice Movement, the idea of applying market-based action to the problem of our territory, Palermo and the Mafia, was sort of a natural thing to do' (interview quoted in Forno \& Gunnarson 2011, 52). Their approach is similar to other grassroots anti-mafia movements of the 1990s that emphasised the citizen's responsibility as well as the state's for fighting organised crime (Jamieson 2000). It adopts what La Spina (2008a, 205) calls the 'indirect' strategy of 'promoting the reaction of civil society against the various forms of mafia type organized crime' but it does so by appealing to the citizen as a consumer.

Adopting the successful model of critical consumerism which encourages people to consider the ethical, social or environmental impact of their purchases (Sassatelli 2006), 
Addiopizzo invites the citizens of Palermo to reflect whether their choice of products helps finance the Mafia's pizzo system. Rather than exercise 'negative' forms of critical consumption such as boycotting (Micheletti 2003, 80), Addiopizzo asks consumers to buy products and services that are supplied by businesses who haven't been asked to pay protection money or who have denounced their extortionists. ${ }^{5}$ By purchasing 'pizzo-free' products from businesses that oppose the pizzo system the consumer is helping to create a free and legal market for the sale of goods. As pizzo-free businesses benefit from the sale of goods to critical consumers so other businesses become motivated to denounce their extortionists too.

Addiopizzo use a variety of tactics to help raise public (and mafia) awareness of their movement whilst protecting the pizzo-free businesses that depend upon it. These range from media and communications to lobbying and civic engagement. Some of their key activities are listed below (Forno and Gunnarson 2011; Zaffuto 2009).

- A logo is prominently displayed by businesses that belong to Addiopizzo in shop windows. It has a dual purpose. It indicates to customers that the business doesn't pay pizzo and warns mafiosi of the risks involved in approaching it for protection money. Evidence of the deterrent effect of Addiopizzo membership was given in April 2010 by a pentito, or mafia turncoat called Giuseppe di Maio. The pizzo collector from the Lo Bocchiaro family of Santa Maria di Gesù, stated that, "If a trader belongs to Addiopizzo or an anti-racket association we don't go there, we do not ask them anything" (Giornale di Sicilia, 30.04.10). A prominently displayed Addiopizzo logo is a clear sign of the business owner's determination to report any approach for money from an extortionist to the police. "There is much concern among us," Di Maio confessed, "[i]f there are informers, then investigations are done and bugs are put in place, it is therefore better to avoid."

- 'La guida per il consumatore critico Addiopizzo' (pizzo-free 'yellow pages') lists all businesses that belong to Addiopizzo. Pizzo-free tourist city maps are also available in English and German. The German language map was financed by the German embassy.

- The Addiopizzo website, www.addiopizzo.org, which went online in August 2004, lists all of its business and consumer members, details of forthcoming events, relevant press cuttings, and a forum. The movement also uses the website to encourage 'riproducibilità' or imitation. Banners and other promotional materials are available to download so that people can set up their own Addiopizzo franchises. The existence of Addiopizzo groups in Catania, Naples and most recently Messina is testament to the movement's diffusion. The site also provides a full balance sheet of the movement's outgoings (www.addiopizzo.org/bilancio.asp) which gives transparency to the operation.

- Addiopizzo Travel (www.addiopizzotravel.it) was launched at the end of 2009 and provides tourists with anti-mafia tours and bespoke holidays at Addiopizzo supporting hotels and pizzo-free restaurants. The travel agency also organises school trips as part of Addiopizzo's educational initiatives.

- In March 2010, Addiopizzo launched a mark that identified goods as 'PRODOTTO PIZZOFREE'. As of April 2011, some 38 manufacturers had products labelled with the Addiopizzo mark. These products include olive oil, honey, organic milk, cheese, clothing and books. A certifying label encourages greater critical consumption by stamping moveable goods as 'pizzo-free'.

- The annual 'Festa Pizzo-Free' (Pizzo-Free Festival and Fair) provides an opportunity for Palermo's citizens to support traders that refuse to pay protection money by purchasing products from their stalls. Debates, workshops and free music are also provided at the three-day events. 
- 'Punto pizzo free - L'emporio' (Pizzo-Free Emporium) was opened in central Palermo in March 2008. It allows consumers to purchase products from a variety of Addiopizzo supporting businesses in a single place. The shop sells wine, baskets, coppola hats, Tshirts and other pizzo-free products.

- Addiopizzo's 'Progetto Scuole' (Schools' Project) whose most recent incarnation is the 'Fortini della legalità' (Forts of Legality) in 2008/9, is an educational initiative funded by the Ministry of Education that promotes legality in Palermo's schools. Addiopizzo also encourages schools to promote 'ethical economics' by only contracting out work to businesses that have publicly declared that they do not pay protection money.

- Addiopizzo also vigorously lobbies public bodies to encourage the regional government to support businesses who have reported their extortionists to the police.

- Addiopizzo works closely with Libero Futuro, Palermo's first anti-racket association, to provide legal assistance to businesses that have reported attempts to extort money to the police.

The recent case of Domenico Davì demonstrates in a concrete way how Addiopizzo uses these methods to support business owners who have had the courage to refuse to pay protection money. Davì, owner of a Sisa supermarket in via Pindemonte in Palermo, was subjected to various acts of intimidation after he had reported a local mafioso, Rosario Lo Nardo, to the police when he demanded protection money from him. Glue was inserted into his locks and one night a petrol bomb was thrown through the shop window causing considerable fire damage. On 2 February 2011, another Molotov cocktail was thrown whilst customers and staff were still inside the shop. This last act of intimidation was designed to scare customers away from the shop and to send a signal to other shopkeepers that refusal to pay pizzo would ultimately end in the failure of their businesses.

Addiopizzo responded to Davì's situation by providing legal and consumer support. In collaboration with Libero Futuro, Addiopizzo gave legal advice to help Davì pursue his complaint against his extortionist through the courts. They also obtained compensation under Region Law 20/99 to cover the cost of the damage caused by the firebombings and had CCTV installed in the store. Addiopizzo also helped to revive Davì's ailing business by distributing leaflets around via Pindemonte to encourage those living nearby to show their support for Davi and his family with their purchases. In the wake of Addiopizzo's actions, Confindustria Sicilia, the employers' federation, authorised an end to a goods embargo placed on Davi's store as a result of delayed payments and Francesco Cascio, president of the Regional Assembly showed his support for Davì's actions against the mafia by visiting the supermarket on 1 March (Giornale di Sicilia, 1.3.2011).

Addiopizzo's response to Davì's plight demonstrates how it supports businesses that refuse to pay protection money and helps mitigate the commercial costs of doing so.

The following sections present the results of the survey of critical consumers.

\section{Method}

A self-administered Opinio $^{7}$ hosted web survey was used to capture responses from consumers that support Addiopizzo. The survey was written in Italian and made up of 15 structured questions (please contact the author for a copy). A likert scale with an even number of responses covering strongly, quite, little and not at all was used to measure agreement and open text questions were used to capture qualitative information. The number of open-ended responses in the survey was limited to discourage drop-out (Bosnjak \& Tuten 2001) and there was no forced-response option allowing respondents to skip questions if they 
wished. The survey was piloted with two native Italian speakers to check that the wording was clear and to estimate how long was needed to complete the survey.

The survey ran for twelve weeks between 19 March and 11 June 2010. The timing coincided with two Addiopizzo events: 'La strada per la denuncia' on 25 March and Liberacittà Addiopizzo: fiera del consumo critico pizzofree $n$. 5, the annual pizzo-free festival and fair between 28-30 May 2010.

A number of measures were taken to maximise the number of responses. Email invitations containing a hyperlink to the web survey were sent out to supporters by a member of the Addiopizzo committee to prevent them from being marked as SPAM. Detailed information on the purpose of the survey was provided and reassurances of anonymity were made - no IP addresses were recorded. A bar showing the percentage of survey completion was provided at the bottom of each page to discourage drop-out and related questions were grouped together in designated sections so that the survey was easy to follow. Contact information was also provided in case respondents had any questions or concerns.

Quantitative response data that was captured in Opinio was exported into Excel and independent and dependent variables were coded in SPSS. Various inferential statistical tests were performed to determine whether there were any statistically significant differences in opinion between respondents with different demographic characteristics. ${ }^{8}$ Qualitative response data were coded manually.

\section{Results}

$51.5 \%$ of the 338 Addiopizzo consumers who responded to the survey were female but males aged between $30-39(52,15.4 \%)$ and over 60 years $(14,4.2 \%)$ were over-represented. 250 respondents reported that they lived in Palermo, 44 outside Palermo but still in Sicily, and 32 on the Italian mainland. Within Palermo itself, $47.2 \%$ of respondents were male and $52.8 \%$ female. This closely mirrors the demographic profile of Palermitans in general. Data for January 2009 from the Italian National Institute of Statistics (Istat) indicate that $47.4 \%$ of those living in Palermo are male $(312,639)$ and $52.6 \%(346,794)$ are female. ${ }^{10}$ However, there were noticeable differences between ages. Those aged between 30-39 years of either sex were over-represented in the survey relative to the population of Palermo. The reverse was true for those aged over 60 years of age. Females aged over 60 years in particular were underrepresented in the survey relative to those resident in Palermo. However, this seems to be compensated for by a higher response rate from females aged 50-59 years. There was also under-representation amongst those aged under 30 years but to a smaller degree.

[Table 1 near here]

A quarter of Palermitan respondents came from the quarter of Libertà (Table 2). This is not surprising given that a high proportion of Addiopizzo consumers in general come from this quarter $(17.6 \%)$. However, there seems to be a higher turnout from Libertà relative to the total proportion of Addiopizzo members resident in that quarter (+7.5\%) compared with other quarters.

[Table 2 near here]

$72.8 \%$ (246) of all respondents reported that they possessed a degree. $77.6 \%$ (135) of all female respondents and 67.7\% (111) of males held a degree. The spread of degrees across age groups was fairly even with older females more likely to report possessing a degree. 
There is a sample of respondents from every year of Addiopizzo's existence despite some over-representation from older members. $77 \%$ of respondents had joined the movement before 2008 .

$86.9 \%$ (286) of respondents had signed the manifesto 'contro il pizzo cambia i consumi' and $21.9 \%$ (72) reported that they had been involved in the 'Pizzo-Free Festival and Fair.' If involvement in the 'Pizzo-Free Festival and Fair' is taken as an indicator of a high level of commitment to Addiopizzo then the typical profile of respondents is: female $(58.3 \%)$ under 30 years of age, living in Palermo (88\%) with a degree $(68 \%)$.

Respondents were also asked if and how regularly they purchased Fairtrade and similar goods as a proxy for ethical consumerism. Unlike the UK, Fairtrade goods are typically only available in dedicated shops in Italy. The overwhelming majority stated that they did buy such goods, particularly chocolate suggesting that our sample of Addiopizzo members are indeed critical in their consumption habits.

But what factors influenced their decision to join Addiopizzo?

[Figure 1 near here]

The main determinant of Addiopizzo membership amongst respondents (171) was that the movement was led by young people. However, an almost equally large number of respondents identified reasons that weren't amongst the options presented. According to the open text responses, Addiopizzo's strategy of empowering individuals to fight the mafia through 'shopping bag power' (Forno \& Gunnarson 2010,110) was particularly appealing. Critical consumption provides citizens with the opportunity 'to do something first-hand'. As one respondent put it: 'supporting Addiopizzo is equivalent to personally fighting the Mafia.'

Some said that they joined Addiopizzo because it was a grassroots anti-mafia movement. 'Finally a new idea that started from the people!' one respondent said. Another reported that they joined because of ' $[t]$ he knowledge that it will change the destiny of society from the bottom.' The fact that Addiopizzo is not driven by the state but by the citizens of Palermo is very important for a significant minority of respondents. This seems to chime with the large number of respondents who reported that Addiopizzo's apolitical stance was an important factor in their decision to support it. ${ }^{9}$ Above all, a strong sense of civic consciousness drove most respondents to join Addiopizzo. One respondent summed it up for many: 'The fight against the pizzo is part of civic conscience.'

The primary reason respondents gave for other consumers not joining Addiopizzo was apathy (Figure 2). The manifesto commitment to purchase pizzo-free products was also seen as a disincentive to membership.

[Figure 2 near here]

The open text responses gave other reasons for non-membership. Many respondents reported that there was insufficient information on pizzo-free shops. Information was described as 'poor' and the amount of publicity 'little'. The experience of the shopkeeper paying protection money was believed to be too far removed from the experience of most consumers. One respondent reported that, 'everyday life seems other to the problem.' Another reported that the lack of wider interest in the campaign was 'as if it were only a problem for businesses and not society.' A number of respondents also identified the patchy distribution or simple lack of pizzo-free shops as a barrier to wider membership. One respondent observed that, 'participating merchants are too few and often concentrated in the same quarter.' Others claimed that other consumers were not supporting 'pizzo-free' businesses 
because other shops are closer to home and often cheaper. 'In Palermo, trade is stifled and people prefer to buy from shops they know, that may offer a discount.'

Finally, some respondents identified cultural barriers to membership that are perceived to be uniquely 'Sicilian'. One respondent described a 'very Sicilian and very convenient sort of "fatalism", which means that things should always be done by others ... "so don't change anything."' Another described the 'tendency to delegate responsibility' and a preference for 'the quiet life'. Some identified these characteristics as symptoms of a deeply rooted mentalità mafiosa which is variously described as a 'laziness, resignation, lack of civic education', and as an 'individualism that prevails over the collective interest'.

Respondents were also asked why the pizzo system had so far not been beaten and which organisations are in a position to tackle it most effectively. The majority of respondents blamed the unwillingness of the political establishment for the continuation of the pizzo system (Figure 3). 73\% of consumers surveyed strongly agreed that politicians were responsible for its perpetuation whilst only $32 \%$ agreed that the strength and ferocity of the mafia was a factor. In fact, a lack of coordination and the weakness of trade associations and the poor support of citizens were held more strongly as factors than the mafia. Few respondents blamed ineffective law enforcement or the weakness of anti-racket associations as factors responsible for the failure to eliminate the pizzo. This support for the police may reflect their recent successes against organised crime such as the arrest of Salvatore Lo Piccolo in November 2007.

[Figure 3 near here]

Interestingly, female respondents were significantly more likely than men to strongly agree that the unwillingness of the political classes was a factor in the failure to eliminate the pizzo. Female respondents and those living in mainland Italy also differed significantly from men and Sicilian residents in the strength of their agreement about the responsibility of trade associations for the continuation of the pizzo system.

Most of those who reported their opinion of the importance of different groups and associations at eliminating the pizzo strongly agreed that they were all important.

[Figure 4 near here]

However, there was a significant difference in ratings on the responsibility of anti-racket associations for eliminating the pizzo between those aged between 50-59 years and those aged under 30 years. This indicates that respondents aged between 50-59 years more strongly agreed that anti-racket associations were responsible for eliminating the pizzo than those under 30.

The overwhelming majority of respondents also thought that Addiopizzo would exist in 5 years time $(84.7 \%)$ and that both businesses and consumer numbers would continue to grow at a similar rate. There was no significant difference in respondents' ratings between groups.

\section{Discussion}

\section{Methodological strengths and weaknesses of the study}

Those who responded to the survey were not a representative sample of the Italian population but a self-selecting sample of Addiopizzo consumers who had access to the Internet. This has two key implications. Firstly, the answers provided are unrepresentative of Italian consumers and more importantly Addiopizzo supporters themselves. 338 critical consumers responded 
to the survey out of a total population of 9,901 Addiopizzo supporters giving a response rate of only $3.4 \%$. The $3.4 \%$ is self-selected and therefore likely to be different from the Addiopizzo consumers that didn't respond to the survey. ${ }^{11}$ Those that responded showed volunteer bias, a greater willingness to take part in surveys than other Addiopizzo consumers. However, deliberately targeting Addiopizzo consumers rather than Italian consumers in general and the subsequent low response rate remain acceptable for a number of reasons:

1) The objective of this study was to gain an insight into the views of Addiopizzo consumers. Subjective information was sought rather than hard facts.

2) Web surveys typically have an $11 \%$ lower level of response than other more traditional methods such as mail or telephone surveys (Manfreda et al. 2008, 79; Shih and Fan 2008).

3) The author did not know the respondents. A relationship with respondents would probably have made them more likely to respond.

The second consequence of the chosen survey design was that one key question became hypothetical. Asked why other Italian consumers were not joining Addiopizzo the respondent could only supply possible but not actual reasons. However, one respondent neatly summarised the weakness but also strength of surveying only Addiopizzo consumers. Asked what factors may explain the reluctance of other consumers to support pizzo-free businesses, the respondent said: 'I cannot specify because I live in the north.' He or she cannot speak for other consumers because they are far removed from the situation in Sicily but those living there can see likely reasons at first-hand. Indeed, as the web survey was administered anonymously the respondents could give honest answers that were sometimes critical of the movement that they supported.

As far as the author is aware, this is the first published survey of Addiopizzo consumers even if only a non-randomly selected sample - and therefore represents a valuable insight into the attitudes of consumers who support businesses that refuse to pay protection money.

\section{Analysis of results}

The names of the first 3,500 consumers to sign Addiopizzo's campaign 'contro il pizzo cambia i consumi' were published in May 2005 in the newspaper Giornale di Sicilia. A year later the first 100 businesses that had never paid or had refused to pay pizzo were also published and presented at the first 'pizzo-free' festival and fair. Figure 5 shows the level of consumer and business membership over the six years between May 2005 and the time of writing, April 2011. All members regardless of residence or place of trading are shown.

[Figure 5 near here]

The number of consumers signing Addiopizzo's campaign almost doubled in the year between their publication in the Giornale di Sicilia and the announcement of the first 100 pizzo-free businesses in May 2006. Some 7,347 consumers had pledged to consume critically from businesses that refused to pay protection money in May 2006. However, the rate of new consumers joining the campaign began to slow during the following year. Between May 2006 and May 2007 there was a $21.4 \%$ rise in new members $(1,574)$, which dropped the following year to $4.5 \%$ or 397 new members. Between April 2008 and April 2011, the number of consumers rose by only $8.3 \%$ from 9,318 to 10,090 . Over the same period, the number of pizzo-free businesses jumped by $173 \%$ from 252 to 688 . Why are no new consumers coming forward to support the businesses that have decided to publically denounce the pizzo system? The survey has provided some possible answers. 
Apathy, ignorance, culture and a shortage of pizzo-free shops were reported by respondents to be the most likely barriers to wider support for the Addiopizzo movement. The sparse distribution of pizzo-free businesses in some quarters was assumed to discourage many from patronising businesses that refuse to pay protection money. Figure 6 maps the diffusion of Addiopizzo businesses and the consumers that support them.

\section{[Figure 6]}

The uneven distribution of Addiopizzo consumers in Palermo seems to be linked to the diffusion of pizzo-free businesses. The correlation between pizzo-free businesses and consumers is 0.8 , indicating a strong relationship. Clearly if pizzo-free businesses are not trading in the same district that critical consumers are resident or work within then few will support them with their purchases.

Some respondents identified the state of being Sicilian, sicilianità, as a barrier to wider support for Addiopizzo. There were 15 direct references to the Sicilian mentality being a factor in the reluctance of many consumers to support pizzo-free businesses. Echoing writers like Pirandello, Sciascia, and Tomasi di Lampedusa, one respondent described a 'kind of "fatalism" that is very Sicilian and very convenient, which means that things should be always done by others ... so nothing changes." The resignation described could explain the apathy and ignorance that many other respondents reported as barriers. '[T]hey don't consider it "their" problem, fundamentally they don't believe in the possibility of change.'

Stolle et al (2011) explain comparatively low levels of political consumerism in Southern and Eastern Europe by appealing to 'the political history and political culture of the countries as well as the official and civic distribution of information to citizens on labeled goods and their availability in stores and mainstream supermarkets' (5). ${ }^{12}$ This seems to fit well with the likely reasons for the weak mobilization of critical consumers in Sicily. The shortage of pizzo-free shops is clearly a barrier to wider participation but blaming political history and culture for low membership seems a little simplistic.

The author of The Leopard, Giuseppe Tomasi di Lampedusa, had a very pessimistic view of Sicilians describing their 'impermeability to anything new' (Lampedusa 2007, 109). He attributed their fatalism, their inability to control their own destiny to 2,500 years of invasion and occupation by a succession of foreign powers (Gilmour 1996, 174). However, the appearance of Addiopizzo seems to indicate a change in attitude and a growing desire to control Sicily's destiny. One of the respondents stated that they joined Addiopizzo because 'it fights effectively for the rebirth of the land that I love.' Others emphasised the importance of Addiopizzo being a grassroots movement created by Sicilians. 'Finally a new idea that started from the people!' Addiopizzo represents a radical change in attitude that is separate from sicilianità but still embedded in Sicilian culture. As the Schneiders (2006) put it: 'antimafia activism has roots in a cultural milieu different from the renunciation and pessimism, the clientelism and patriarchy, that so many commentators inside and outside, regard as integral to the Sicilian essence' (75). Addiopizzo is a product of Sicilian culture but its static consumer membership may reflect its minority status.

Paul Ginsborg distinguishes between two middle classes, a reflexive middle class (2001; 2004), of highly educated civil servants, university professors, and social workers who are involved in 'deliberative democracy, fair trade and responsible consumption, immigrant rights ...' etc $(2004,171)$ and the small entrepreneurs and shopkeepers who make up the nonreflexive majority and are characterised as 'localistic, consumerist, strongly oriented both to self-interest and an over-riding work ethic' (2001, 66). As our sample of Addiopizzo members were mostly educated to degree-level and are active critical consumers they can be said to belong to Ginsborg's reflexive middle class. Perhaps, the individualistic and localistic 
mentality of the majority of the Palermitan middle class blocks their wider support for pizzofree businesses.

However, substituting a culturally essentialist interpretation with one based on class is unhelpful especially when it doesn't explain the reluctance of those from more deprived areas of Palermo like Brancaccio to support pizzo-free businesses. A more prosaic reason for nonparticipation in Addiopizzo's initiative is poor publicity. Apathy and ignorance can equally be symptoms of a lack of publicity as a purported mentalità mafiosa or an unreflective middle class. One respondent reported that other consumers weren't supporting pizzo-free businesses 'because the committee invests very little effort to engage the consumer.' Others described 'little publicity', 'poor information', 'not the right amount of advertising' and 'not always adequate and comprehensive information'. Ignorance can be attributed in large measure to this lack of publicity and apathy to a failure to make the plight of business owners who pay pizzo relevant to the ordinary consumer.

Ultimately, the survey data collected in this study was inadequate to answer why the majority of consumers in Palermo tolerate the pizzo system by patronising businesses that aren't pizzo-free. ${ }^{13}$ Despite this, Mete's (2008a) survey of shopkeepers does permit some comparison of the attitudes of Addiopizzo consumers with a more representative sample of Palermitans. ${ }^{14}$ Of the 824 shopkeepers that responded to Mete's survey, 90.7\% strongly agreed that the pizzo was a violent and unjustified act. Fear of reprisal was the primary reason that respondents gave for the payment of protection money but shopkeepers also held other factors responsible for the perpetuation of the pizzo system. Over half of respondents $(54.1 \%)$ identified the strength and ferocity of the mafia itself as a factor but most $(60 \%)$ blamed the unwillingness of the political classes to tackle it. The inability of fellow business owners to organise themselves into action (45.6\%) and the weak support of fellow citizens $(41.9 \%)$ were also cited as very important factors.

These attitudes broadly correspond to those expressed by the Addiopizzo consumers surveyed. However, whilst the proportion of critical consumers and shopkeepers who blamed civil society for the persistence of the pizzo system was the same, Addiopizzo consumers were much more likely to blame the political establishment for its durability.

Addiopizzo is resolutely non-partisan because it believes that not all politicians can be trusted. ${ }^{15}$ However, the broader mass of Palermitan society is not averse to electing politicians with known links to the Mafia. In the 2006 regional election, Salvatore Cuffaro was successfully re-elected as President of Sicily with $52.2 \%$ of the vote despite being investigated for favoreggiamento or aiding and abetting the Mafia (The Independent 30.05.2006). ${ }^{16}$ This electoral support reflects a wider complicity with the Mafia amongst Palermo's citizens that both the shopkeepers and consumers surveyed blame for the persistence of the pizzo system. Cuffaro's party, the Unione dei Democratici Cristiani e di Centro (UDC) was the second largest party in Palermo with $19 \%$ of the vote in the 2006 elections (Corriere della Sera, 29.05.06). Such complicity is a feature of the clientelistic structure of Palermitan society (Chubb 1982; Cole 1997; Schneider \& Schneider 2003; Orlando 2011). If consumers, particularly those from the poorer districts of Palermo, depend upon clientelistic networks because of the scarcity of food and jobs then Addiopizzo needs to help create an alternative support network. ${ }^{17}$ Back in 1997, Patrick McCarthy predicted that protesting social groups like the anti-Mafia movement in Sicily "will not be able to realize their goals merely by gaining a greater share of power in a clientelistic state. [...] Rather they will have to create a state [...] in which the market functions and public goods are not sold to the highest bidder but are distributed in a manner that is recognizably fairer and more efficient" $(1997,241)$. Palermo's citizens will continue to indirectly finance the pizzo system unless they can be persuaded to join together and use their 'shopping bag power' as 
consumers to create an alternative support network that rewards businesses who want to operate in a free and legal market.

\section{Policy recommendations}

The following policy recommendations are informed by the responses given in the survey and are intended to help Addiopizzo publicise their initiative and thereby encourage more consumers to buy pizzo-free.

The number of new consumers supporting the movement has declined considerably over the last couple of years and those that are members seem to come from 'a specific and welleducated strata' (Forno \& Gunnarson 2008, 22) that live in the more prosperous parts of Palermo. The consumers who responded to the survey that reported having a degree was certainly disproportionate and many resided in the richer area of Libertà. Targeting consumers from more disadvantaged backgrounds is essential if the pizzo system is to be tackled by Palermitan society as a whole. The paucity of pizzo-free businesses in the more deprived quarters of Palermo such as Brancaccio make this difficult but businesses themselves will not publically denounce the pizzo unless they have consumers prepared to support them with their purchases. Addiopizzo might encourage more consumers from less privileged backgrounds by making critical consumption more financially attractive. A few of the respondents mentioned that discounts would incentivise consumers to spend at 'pizzo-free' businesses. One successful model is the Tastecard used in the UK which offers members substantial discounts in participating restaurants. Charging an annual fee for the card would help subsidise the cost of the discount to participating 'pizzo-free' businesses.

A number of consumer respondents identified a lack of information on pizzo-free shops as a possible reason for non-membership. Consumers didn't know where their nearest pizzo-free shop was. This was mentioned by respondents living in Palermo as well as outside it. The provision of information on pizzo-free businesses could be improved with a smartphone application for example.

Many Sicilian goods such as wine and fruit are available in supermarkets outside Italy that are not labelled as 'pizzo-free'. Encouraging product buyers from such stores to stock pizzofree goods would help increase sales and boost publicity of Addiopizzo's campaign abroad.

\section{Acknowledgements}

The author wishes to thank the following people for their invaluable help during this project: Jyoti Belur, Rachel Carson, John Dickie, Francesca Forno, Siwan Hayward, Giovanni Orlando, Marco Siino, Lucia Summers, and Francesca Vannini Parenti. In particular, I am grateful to Kià Capri and Vittorio Mete for their generosity and patience. I also want to thank all of those critical consumers who responded to my survey. Thanks also to my anonymous reviewers for their insightful comments. Any errors are of course mine. 


\section{Notes}

1. As recorded on www.addiopizzo.org on $19^{\text {th }}$ April 2011.

2. Forno and Gunnarson call it 'shopping-bag power' $(2011,51)$.

3. Forgione (2009) has shown that the Mafia's pizzo system extends well beyond Italy but so do antimafia attempts to resist it. In late 2007, a cultural initiative called Mafia? Nein Danke! was set up after the massacre in the German city of Duisburg that left several members of the 'Ndrangheta dead. Later that year, the campaign was instrumental in the prosecution of a number of camorristi who had threatened Italian restaurants in Berlin with demands for protection money. The campaign's website is www.mafianeindanke.de. The movement was founded by Laura Garavini following the model of Addiopizzo (see www.garavini.eu/?page $\mathrm{id}=486$ ).

4. www.addiopizzo.org/nascita.asp

5. See their manifesto: www.addiopizzo.org/manifesto.asp

6. Forno also discusses Libera Terra, an agricultural co-operative that cultivates land seized from the Mafia under Regional Law 109/96.

7. For information on Opinio see www.objectplanet.com/opinio

8. Mann-Whitney $U$ and Kruskal Wallis statistical tests were performed to investigate differences between the medians of groups in the responses to questions 1, 7, 9 and 10 (Field 2009). Non-parametric tests were used because the author couldn't assume that the respondents perceived the difference between adjacent levels on a likert scale to be equal (Jamieson 2004) and so the data was taken to be interval rather than ordinal.

9. The wording of this question unfortunately blurs the distinction between being apolitical and non-partisan which are quite different. Addiopizzo is non-partisan but defiantly political in its desire to eradicate a system that has spread throughout Sicilian society.

10. Extracted from demo.istat.it/pop2009/index e.html on 12 July 2010.

11. Unfortunately, the author did not have access to demographic data on Addiopizzo's consumers so non-respondence could not be examined. However, it could be argued that the low response rate reflected a lack of active Addiopizzo consumers.

12. According to the European Social Survey, Italy recorded the lowest percentage of 20-29 year olds engaged in political consumerism of 21 different European countries and Israel (Stolle et al 2011, 15). Boycotting and buycotting were most prevalent in the Nordic countries.

13. Orlando (2011) argues that the lives of Palermo's middle class critical consumers are insulated from working class citizens who are dependent upon 'a scarcity-based clientelism' that provides food, cash and job promises (224, 218; Cole 1997). The 'culturalist' reasons that they provide for low levels of critical consumption in Palermo's poorer districts are therefore partial at best.

14. Two of the questions used in the survey of Addiopizzo consumers derived from Mete's surveys (Q1; Q7). The results from a second wave of the survey (Palermo Vista Racket 2) are expected to be published later in 2011.

15. The former mayor of Palermo, Leoluca Orlando, and of Gela, Rosario Crocetta, are amongst the honourable exceptions.

16. His challenger, Rita Borsellino, sister of the antimafia magistrate Paolo, received $43 \%$ of the vote. Cuffaro was jailed in January 2011 for 7 years after the Court of Cassation, Italy's Supreme Court, upheld his conviction for favoreggiamento aggravato of Cosa Nostra (Corriere della Sera, 22.01.11).

17. Following Chubb (1982) and Cole (1997), Orlando argues that '[w]hile scarcity is more of an issue for the city's popular classes, the middle class is also involved in patronage, though the manner of its involvement differs and its members manage to escape the most 
severe forms of clientelism' $(2011,218)$. Clientelism amongst the middle classes typically involves an exchange of favours such as bureaucratic mediation.

\section{References}

Asmundo, A. and M. Lisciandra. 2008. The cost of protection racket in Sicily. Global Crime 9, no. 3: 221-240.

Bosnjak, M. and T. L. Tuten. 2001. Classifying Response Behaviors in Web-based Surveys. Journal of Computer-Mediated Communication 6, no. 3.

Ciconte, E. 2008. Storia criminale. La resistibile ascesa di mafia, 'ndrangheta e camorra dall'Ottocento ai giorni nostri. Soveria Mannelli: Rubbettino Editore.

Chubb, J. 1982. Patronage, Power and Poverty in Southern Italy: A Tale of Two Cities. Cambridge: Cambridge University Press.

Cole, J. 1997. The new racism in Europe: a Sicilian ethnography. Cambridge: Cambridge University Press.

Dickie, J. 2007. Cosa Nostra: A History of the Sicilian Mafia. 2nd edition. London: Hodder.

Dickie, J. 1999. Darkest Italy: The Nation and Stereotypes of the Mezzogiorno, 1860-1900. London: MacMillan.

Dillman, D. A. 2000. Mail and Internet surveys: The total design method ( $2^{\text {nd }}$ ed.). New York: Wiley.

Field, A. 2009. Discovering Statistics Using SPSS: (and sex, drugs and rock ' $n$ ' roll). London: Sage Publications Ltd.

Forgione, F. 2009. Mafia export. Come 'ndrangheta, cosa nostra e camorra hanno colonizzato il mondo. Milan: Baldini Castoldi Dalai.

Forno, F. and Gunnarson, C. 2011. Combattere la mafia facendo la spesa: la svolta di Addiopizzo. In La spesa a pizzo zero: Consumo critico e agricoltura libera. Le nuove frontiere della lotta alla mafia ed. F. Forno. 44-65. Roma: Altreconomia.

Forno, F. and C. Gunnarson. 2010. Everyday shopping to fight the Italian Mafia. In Creative Participation: Responsibility-taking in the Political World, eds. M. Micheletti and A. MacFarland, 103-126. Boulder, CO: Paradigm Publishers.

Forno, F. and C. Gunnarson. 2008. Everyday Shopping to Fight the Italian Mafia. Paper presented at the Annual SISP Conference, Pisa, 4-6 September.

Gambetta, D. 1993. The Sicilian Mafia: The Business of Private Protection. London: Harvard University Press.

Gilmour, D. 1996. The Last Leopard, London: Harvill Press.

Di Gennaro, G. and La Spina, A. 2010. I costi dell'illegalità. Camorra ed estorsioni in Campania. Bologna: Il Mulino.

Ginsborg, P. 2004. Silvio Berlusconi: television, power and patrimony. London: Verso.

Ginsborg, P. 2001. Italy and its discontents: family, civil society, state, 1980-2001. London: Penguin.

Jamieson, A. 2000. The Antimafia: Italy's fight against organized crime. London: Macmillan Press.

Jamieson, S. 2004. Likert scales: how to (ab)use them. Medical Education 38: 1212-1218

di Lampedusa, T. 2007. The Leopard, trans A. Colquhoun. London: Vintage.

Lisciandra, M. 2010. Camorra ed estorsioni: una stima del costo per le imprese. In I Costi dell'Illegalità - Camorra ed estorsioni in Campania, eds. G. Di Gennaro and A. La Spina, 161-184. Bologna: Il Mulino.

Manfreda, K. L., M. Bosnjak, J. Berzelak, L. Haas, and V. Vehovar. 2008. Web surveys versus other survey modes. International Journal of Market Research 50: 79-104. 
McCarthy, P. 1997. The Crisis of the Italian State: from the origins of the Cold War to the fall of Berlusconi and beyond. New York: St Martin's Press.

Mete, V. 2008a. Il pizzo visto dai commercianti. In Palermo: vista racket. La scuola interroga i commercianti del quartiere, various authors, 21-39. Palermo: Comitato Addiopizzo.

Mete, V. 2008b. I costi dell'illegalità di Antonio La Spina. Sociologica 1/2008: 1-6.

Micheletti, M. 2010. Introduction: Responsibility-Taking in Politics. In Creative Participation: Responsibility-taking in the Political World, eds. M. Micheletti and A. MacFarland, 1-14. Boulder, CO: Paradigm Publishers.

Micheletti, M. 2003. Political Virtue and Shopping: Individuals, Consumerism, and Collective Action. New York: Palgrave.

Orlando, G. 2011. Critical consumption in Palermo: imagined society, class and fractured locality. In Ethical consumption: social value and economic practice, eds. J.G. Carrier and P. Luetchford, 203-233. Oxford: Berghahn.

Santino, U. 2000. Storia del Movimento Antimafia: Dalla Lotta di Classe all'Impegno Civile. Roma: Editori Riuniti.

Sassatelli, R. 2006. Virtue, Responsibility and Consumer Choice. Framing Critical Consumerism. In Consuming Cultures, Global Perspectives, eds. J. Brewer and F. Trentmann, 219-250. Oxford: Berg.

Schneider, J. and P. Schneider. 2006. Sicily: reflections on forty years of change. Journal of Modern Italian Studies 11, no. 1: 61-83.

Schneider, J. and P. Schneider. 2003. Reversible Destiny: Mafia, Antimafia, and the Struggle for Palermo. Berkeley and Los Angeles: University of California Press.

Schneider, J. (ed.) 1998. Italy's 'Southern Question': Orientalism in One Country. Oxford: Berg.

Sciarrone, R. 2009. Mafie Vecchie, Mafie Nuove. 2nd edition. Roma: Donzelli editore.

Shih, T. H., and X. Fan. 2008. Comparing response rates from web and mail surveys: A meta-analysis. Field Methods 20: 249-271.

SOS Impresa, 2010. Le Mani Della Criminalità Sulle Imprese, XII Rapporto. Roma. Available online at: www.sosimpresa.it/userFiles/File/Iniziative/XII_RAPPORTO_SOS_IMPRESA_SINTESI_PER LA STAMPA.pdf

SOS Impresa, 2007. Le Mani Della Criminalità Sulle Imprese, X Rapporto. Roma. Available online at: www.sosimpresa.it/userFiles/File/Documenti1/Microsoft_Word__Progress_2007_Lino_Bus_.pdf

La Spina, A. 2008a. Recent Anti-Mafia Strategies: The Italian Experience. In Organized Crime: Culture, Markets and Policies, ed. D. Siegel and H. Nelen, 195-206. New York: Springer.

La Spina, A. (ed) 2008b. I costi dell'Illegalità - Mafia ed estorsioni in Sicilia. Bologna: Il Mulino.

Stolle, D., M. Micheletti and D. Berlin. 2011. Young People and Political Consumerism. Originally published in Swedish as 'Politik, konsumtion och delaktighet' in Fokus 10. En analys av ungas inflytande. Available online at: http://www.sustainablecitizenship.com/pdf/Young-People-and-Political-Consumerism.pdf

Varese, F. 2011. Mafias on the Move: How Organized Crime Conquers New Territories. Princeton: Princeton University Press.

Varese, F. 2006. How Mafias Migrate. Law and Society Review 40, no. 2: 411-444.

Varese, F. 2001. The Russian Mafia. Private Protection in a New Market Economy. Oxford: Oxford University Press.

Zaffuto, E. 2009. From pizzo to Addiopizzo: 2004-2009, Paper presented at the 
Clinton School of Public Service, 27 April 2009. Available online at: www.clintonschoolspeakers.com/lecture/view/addiopizzo/

\section{Tables and figures}

Table 1: Sample profile

\begin{tabular}{|l|c|c|}
\hline & Total & \% \\
\hline Base & 338 & - \\
\hline Gender & & \\
\hline Male & 164 & $48.5 \%$ \\
Female & 174 & $51.5 \%$ \\
\hline Age & & \\
\hline Less than 30 years & 114 & $33.8 \%$ \\
$30-39$ & 96 & $28.5 \%$ \\
$40-49$ & 53 & $15.7 \%$ \\
$50-59$ & 52 & $15.4 \%$ \\
Over 60 years & 22 & $6.5 \%$ \\
\hline Place of residence & & \\
\hline Palermo & 250 & $76.7 \%$ \\
In Sicily outside Palermo & 44 & $13.5 \%$ \\
Mainland Italy & 32 & $9.8 \%$ \\
\hline Degree & & \\
\hline Yes & 246 & $72.8 \%$ \\
No & 92 & $27.2 \%$ \\
\hline
\end{tabular}

Table 2: Profile of sample and population by quarter of residence

\begin{tabular}{|r|cc|cc|c|}
\hline Quarter & Respondents & $\mathbf{\%}$ & Population & $\mathbf{\%}$ & $\mathbf{\% ~ d i f f ~}$ \\
Altarello & 2 & 0.8 & 81 & 1.2 & -0.4 \\
Arenella & 1 & 0.4 & 55 & 0.8 & -0.4 \\
Boccadifalco & 3 & 1.2 & 121 & 1.7 & -0.5 \\
Borgo Nuovo & 3 & 1.2 & 101 & 1.4 & -0.2 \\
Brancaccio-Ciaculli & 4 & 1.6 & 66 & 0.9 & 0.7 \\
Castellammare & 4 & 1.6 & 82 & 1.2 & 0.4 \\
Cruillas-CEP & 5 & 2.0 & 201 & 2.9 & -0.9 \\
Cuba-Calatafimi & 5 & 2.0 & 297 & 4.2 & -2.2 \\
Libertà & 62 & 24.9 & 1,230 & 17.6 & 7.3 \\
Malaspina-Palagonia & 18 & 7.2 & 454 & 6.5 & 0.7 \\
Mezzomonreale-Villatasca & 8 & 3.2 & 234 & 3.3 & -0.1 \\
Monte di Pietà & 2 & 0.8 & 91 & 1.3 & -0.5 \\
Montepellegrino & 10 & 4.0 & 234 & 3.3 & 0.7 \\
Noce & 7 & 2.8 & 197 & 2.8 & 0.0 \\
Oreto-Stazione & 8 & 3.2 & 293 & 4.2 & -1.0 \\
Palazzo Reale & 2 & 0.8 & 85 & 1.2 & -0.4 \\
Pallavicino & 4 & 1.6 & 149 & 2.1 & -0.5 \\
Partanna Mondello & 4 & 1.6 & 212 & 3.0 & -1.4 \\
Politeama & 20 & 8.0 & 541 & 7.7 & 0.3 \\
Resuttana-San Lorenzo & 32 & 12.9 & 784 & 11.2 & 1.6 \\
Santa Rosalia-Montegrappa & 3 & 1.2 & 134 & 1.9 & -0.7 \\
Settecannoli & 2 & 0.8 & 133 & 1.9 & -1.1 \\
Tommaso Natale-Sferracavallo & 6 & 2.4 & 205 & 2.9 & -0.5 \\
Tribunali & 8 & 3.2 & 151 & 2.2 & 1.1 \\
Uditore-Passo di Rigano & 9 & 3.6 & 343 & 4.9 & -1.3 \\
Villagrazia-Falsomiele & 2 & 0.8 & 162 & 2.3 & -1.5 \\
Zisa & 15 & 6.0 & 363 & 5.2 & 0.8 \\
\hline & & & & & \\
\hline & & & & \\
Total & $\mathbf{2 4 9}$ & & & \\
\hline
\end{tabular}


Figure 1: Factors influencing decision to join Addiopizzo (Source: Question 3)

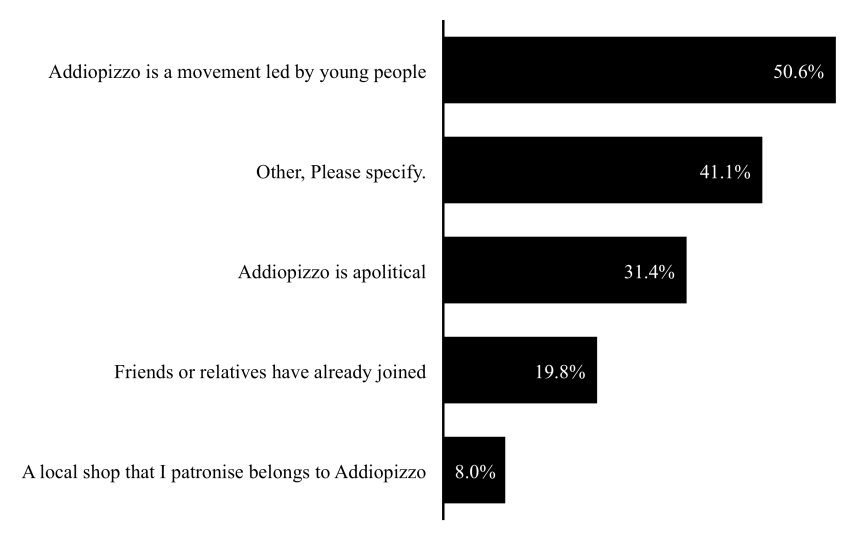

Figure 2: Likely reasons for non-membership of Addiopizzo (Source: Question 5)

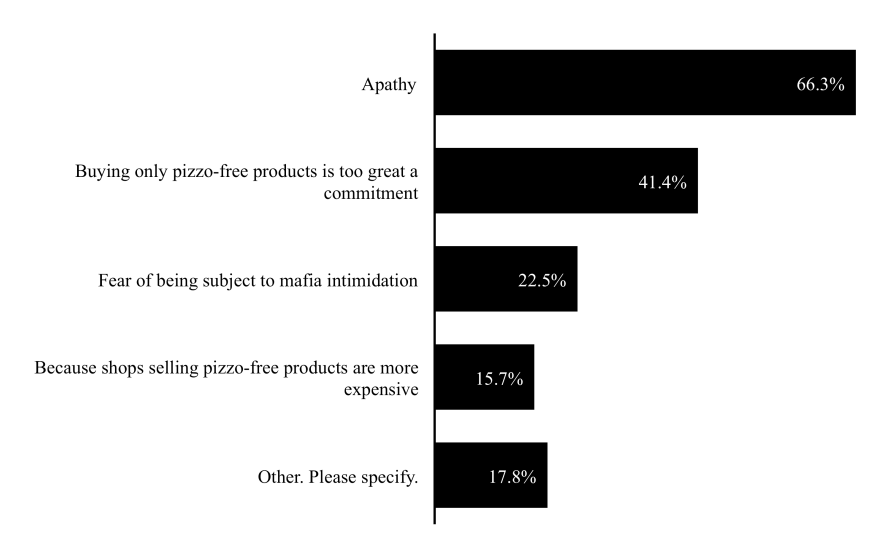

Figure 3: Reasons for the persistence of the pizzo system (Source: Question 7) 


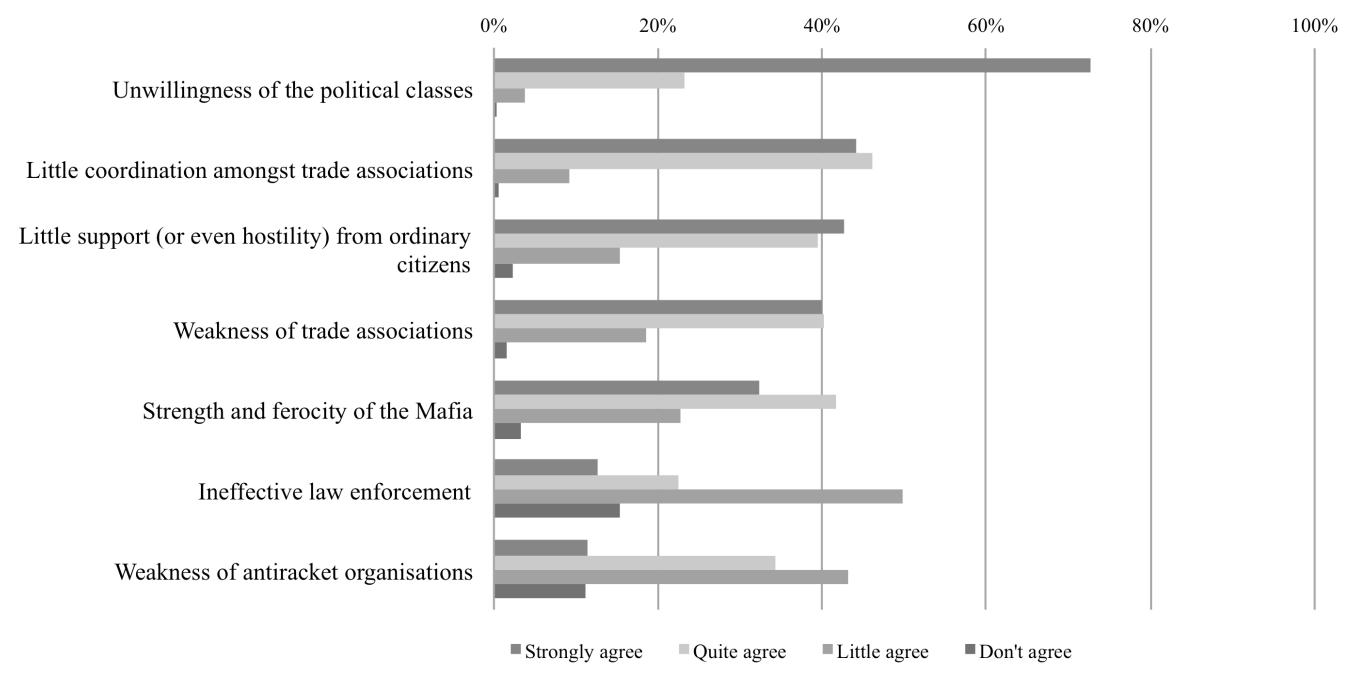

Figure 4: Importance of the actions of various organisations and groups at eliminating the pizzo system (Source: Question 1)

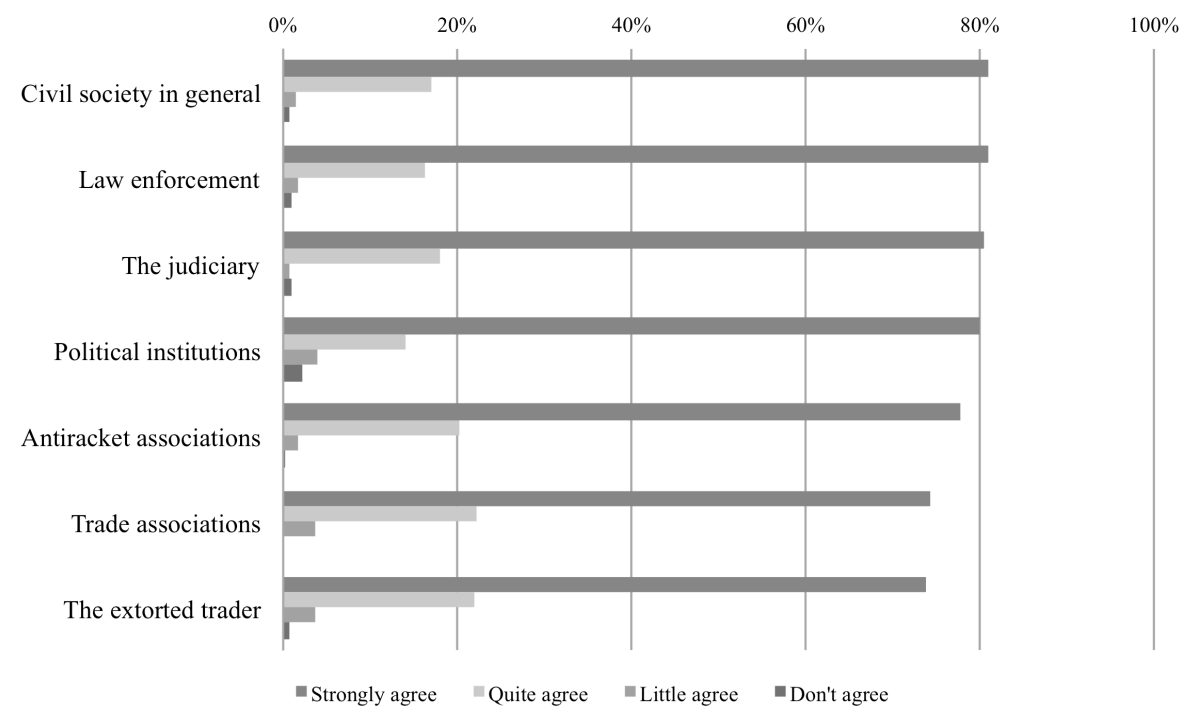

Figure 5: Levels of Addiopizzo membership, May 2005-April 2011 


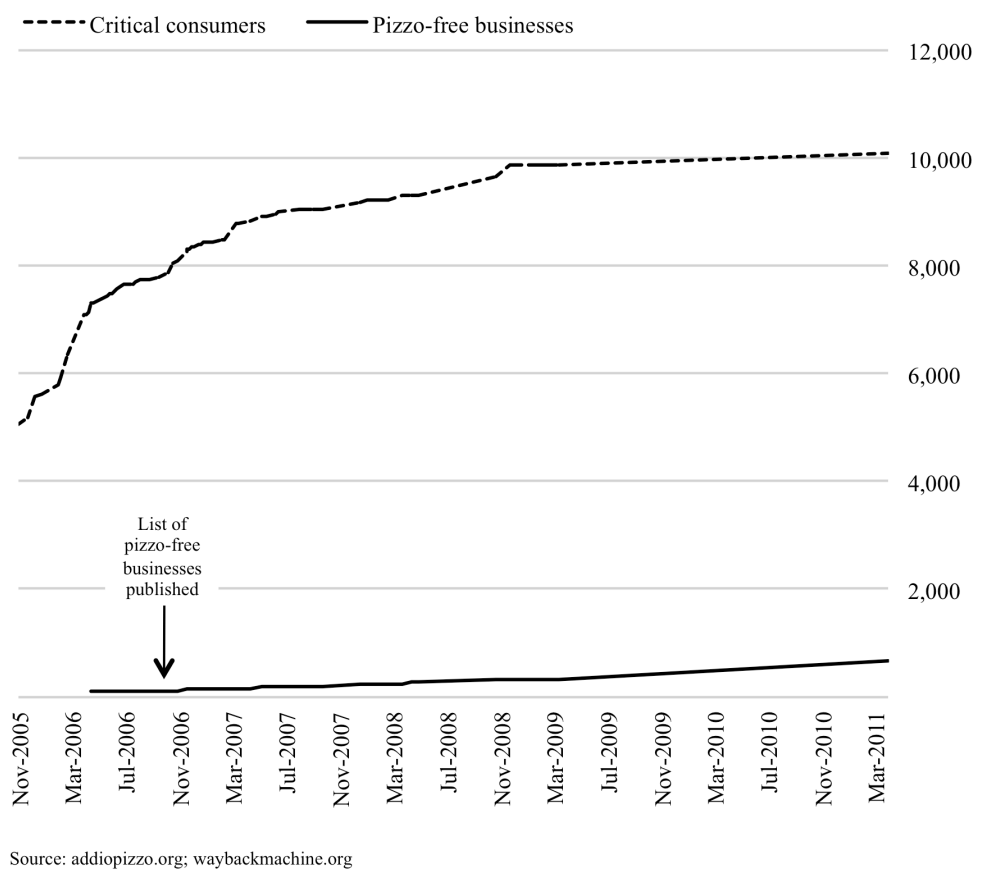

Figure 6: The diffusion of pizzo-free businesses and Addiopizzo consumers in the quarters of Palermo in March 2010.

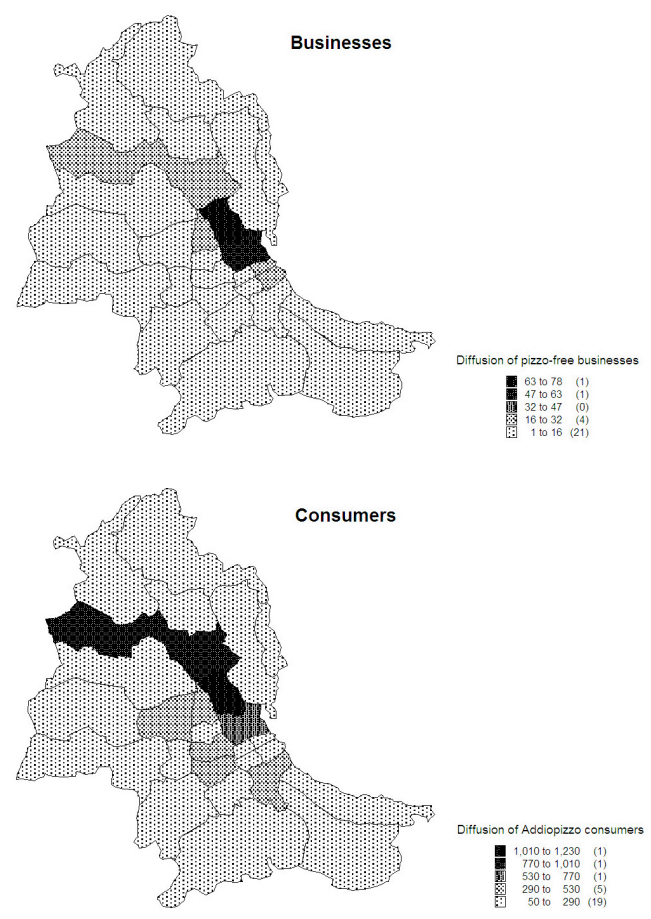


